\title{
Heavy Metals Pollution and Pb Isotopic Signatures in Surface Sediments Collected from Bohai Bay, North China
}

\author{
Bo Gao, ${ }^{1,2}$ Jin Lu, ${ }^{1}$ Hong Hao, ${ }^{1}$ Shuhua Yin, ${ }^{1}$ Xiao Yu, ${ }^{1}$ Qiwen Wang, ${ }^{1}$ and Ke Sun ${ }^{3}$ \\ ${ }^{1}$ State Key Laboratory of Simulation and Regulation of Water Cycle in River Basin, China Institute of Water Resources and \\ Hydropower Research, Beijing 100038, China \\ ${ }^{2}$ Department of Water Environment, China Institute of Water Resources and Hydropower Research, Beijing 100038, China \\ ${ }^{3}$ State Key Laboratory of Water Environment Simulation, School of Environment, Beijing Normal University, Beijing 100875, China
}

Correspondence should be addressed to Ke Sun; sunke@bnu.edu.cn

Received 27 October 2013; Accepted 5 March 2014; Published 10 April 2014

Academic Editors: T. Chaminda, K. Kuroda, and G. Singh

Copyright (C) 2014 Bo Gao et al. This is an open access article distributed under the Creative Commons Attribution License, which permits unrestricted use, distribution, and reproduction in any medium, provided the original work is properly cited.

To investigate the characteristics and potential sources of heavy metals pollution, surface sediments collected from Bohai Bay, North China, were analyzed for the selected metals $(\mathrm{Cd}, \mathrm{Cr}, \mathrm{Cu}, \mathrm{Ni}, \mathrm{Pb}$, and $\mathrm{Zn})$. The Geoaccumulation Index was used to assess the level of heavy metal pollution. $\mathrm{Pb}$ isotopic compositions in sediments were also measured to effectively identify the potential $\mathrm{Pb}$ sources. The results showed that the average concentrations of $\mathrm{Cd}, \mathrm{Cr}, \mathrm{Cu}, \mathrm{Ni}, \mathrm{Pb}$, and $\mathrm{Zn}$ were $0.15,79.73,28.70,36.56,25.63$, and $72.83 \mathrm{mg} / \mathrm{kg}$, respectively. The mean concentrations of the studied metals were slightly higher than the background values. However, the heavy metals concentrations in surface sediments in Bohai Bay were below the other important bays or estuaries in China. The assessment by Geoaccumulation Index indicated that $\mathrm{Cr}, \mathrm{Zn}$, and $\mathrm{Cd}$ were classified as "the unpolluted" level, while $\mathrm{Ni}, \mathrm{Cu}$, and $\mathrm{Pb}$ were ranked as "unpolluted to moderately polluted" level. The order of pollution level of heavy metals was: $\mathrm{Pb}>\mathrm{Ni}>\mathrm{Cu}>\mathrm{Cr}>\mathrm{Zn}>\mathrm{Cd}$. The $\mathrm{Pb}$ isotopic ratios in surface sediments varied from 1.159 to 1.185 for ${ }^{206} \mathrm{~Pb} /{ }^{207} \mathrm{~Pb}$ and from 2.456 to 2.482 for ${ }^{208} \mathrm{~Pb} /{ }^{207} \mathrm{~Pb}$. Compared with $\mathrm{Pb}$ isotopic radios in other sources, $\mathrm{Pb}$ contaminations in the surface sediments of Bohai Bay may be controlled by the mix process of coal combustion, aerosol particles deposition, and natural sources.

\section{Introduction}

Bohai Bay is a semienclosed bay located in the western region of the Bohai Sea and is one of the four major compositions in Bohai Sea, North China. It covers an area of $1.60 \times 104 \mathrm{~km}^{2}$ with a population of about 70 million. The average depth is $12.5 \mathrm{~m}$ with the maximum of $32 \mathrm{~m}$. Bohai Bay is important harbor and marine lines of economic development in North China. With the rapid development of urban economy and industry around sea, Bohai Bay receives both industrial and domestic wastewater discharges from Beijing, Tianjin, and Hebei province. All the wastewater through rivers and channels drains into the near-shore waters of Bohai Bay directly. This process produced a certain degree of heavy metal pollution for ocean environment [1]. In fact, sediments can receive and absorb metal pollutants from natural weathering, erosion, and anthropogenic activities. Heavy metal concentrations in ocean sediments are important indicators which can reflect the heavy metal pollution of ocean environment [2]. Moreover, heavy metals may be recycled via chemical and biological processes within these sedimentary compartment and back to the water column [3]. The accumulation of metal contaminants in sediments can pose serious environmental problems to the ocean environment. Therefore, identifying the sources of heavy metals is of key importance for making decisions concerning site remediation. Up till now, most researchers have identified the metal sources in sediments by using variations of metal concentrations and enrichment factors relative to natural inputs. However, recent studies have proved that the $\mathrm{Pb}$ stable isotopic signatures were a useful tool to effectively identify various sources of $\mathrm{Pb}$ pollution in water environment [4-6].

In the recent years, the researches of heavy metals in Bohai Bay had mainly focused on the estuarine and the intertidal zone [7-9]. The scale of whole Bay consisting of the estuarine, the intertidal zone, and centre of the Bay was 


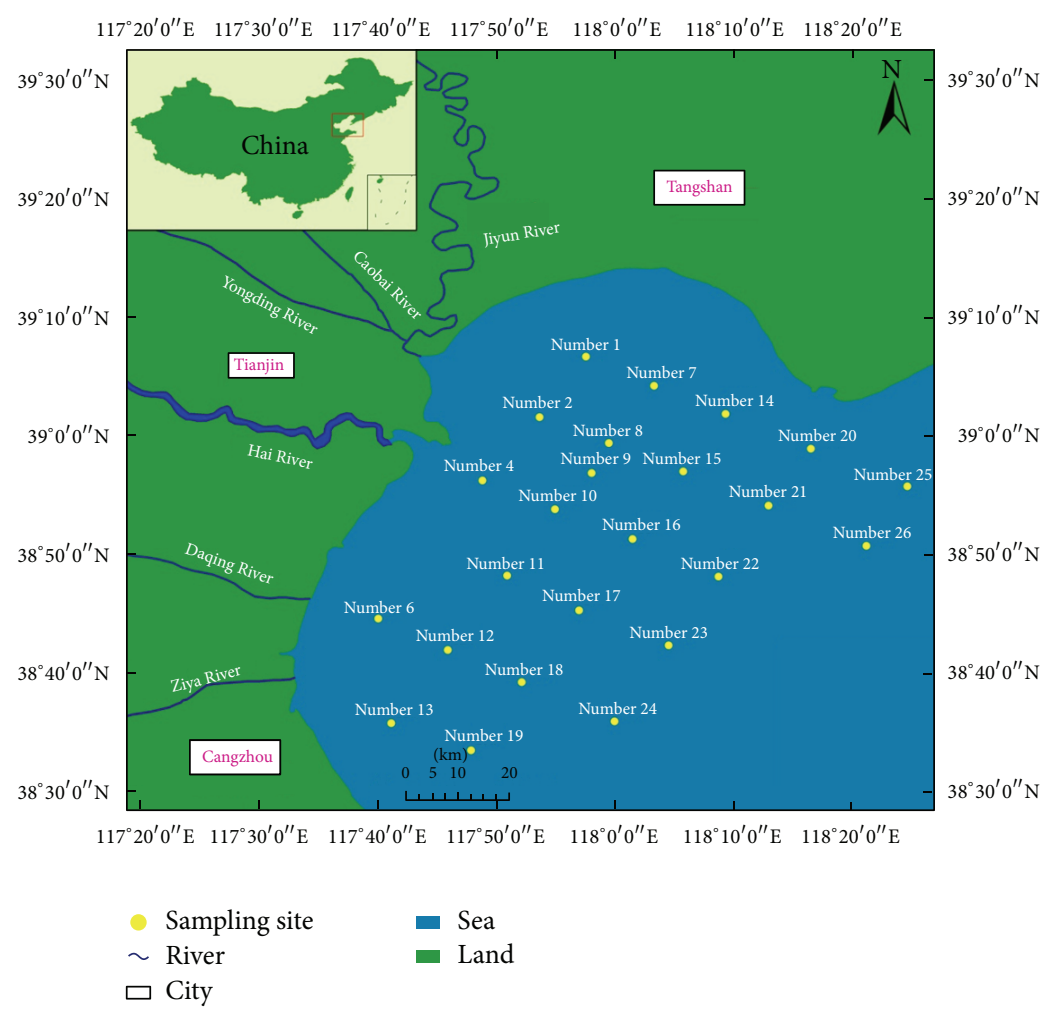

FIGURE 1: Sampling sites in Bohai Bay.

not fully researched for the characteristics of heavy metals pollution. The objectives of this present study were (1) to determine concentrations and distribution characteristics of heavy metals in surface sediments collected from the Bohai Bay, (2) to evaluate the degree of heavy metal contamination, and (3) to identify the metal pollution sources using $\mathrm{Pb}$ isotopic signature. We hope our research on heavy metals contamination and $\mathrm{Pb}$ isotopic signatures will be useful to assess the environmental impact of urbanization and economic development on ocean water environment, while providing scientific information for environmental management and restoration in this region.

\section{Materials and Methods}

2.1. Sampling Sites. Eighteen surface sediments $(0-10 \mathrm{~cm})$ were collected from Bohai Bay, North China. A map of the sampling sites is shown in Figure 1. After sampling, the sediment samples were taken back to indoor laboratory and dried at a temperature below $-40^{\circ} \mathrm{C}$, crushed, and sieved to less than $200 \mu \mathrm{m}$ before the chemical measurements were taken as described below.

2.2. Analytical Methods. All chemical treatments were in the ultraclean laboratory, and all reagents were of high purity grade. A strong acid digestion method $\left(\mathrm{HNO}_{3}+\mathrm{H}_{2} \mathrm{O}_{2}+\right.$ $\mathrm{HF}$ ) was used to dissolve heavy metals in solution [10]. The digested solutions were measured using inductively coupled plasma-mass spectrometry (ICP-MS, Perkin Elmer
Elan DRC-e) for the concentrations of Cd, Cr, Cu, Ni, Pb, and $\mathrm{Zn}$. The accuracy of the analytical procedures employed for the analysis of the metals in sediments was checked using the certified reference material of China stream sediment (GSD12, GBW07312), obtaining good agreement with certified values.

2.3. Pb Isotopic Measurement. Pb isotopic analyses was separated using microexchange columns of anion resin of DowexI (200-400 mesh) and $\mathrm{HBr}$ and $\mathrm{HCl}$ as eluants [11]. Measurements of $\mathrm{Pb}$ isotopic compositions were carried out using an ICP-MS (Perkin Elmer Elan DRC-e). The average measured values of the standard NIST SRM-981 are ${ }^{206} \mathrm{~Pb} /{ }^{207} \mathrm{~Pb}=$ $1.0937 \pm 0.0012$ and ${ }^{208} \mathrm{~Pb} /{ }^{207} \mathrm{~Pb}=2.3695 \pm 0.032(n=$ $20)$, respectively, which were in close agreement with the certified standard values (1.0933 and 2.3704, resp.). Analytical uncertainties in $2 \mathrm{~s}(2 \mathrm{~s}, 2$ standard deviation, $n=20)$ for $\mathrm{Pb}$ isotopic ratios $\left({ }^{206} \mathrm{~Pb} /{ }^{207} \mathrm{~Pb}\right)$ were generally $<0.5 \%$.

\section{Results and Discussion}

3.1. Heavy Metal Concentrations in Surface Sediments. The heavy metal concentrations and statistics results of all investigated sediments in Bohai Bay are summarized in Table 1. For the comparison purpose, the background values of heavy metals and heavy metals concentrations in sediments from the other Bays and Estuaries were also shown. As can be seen, the concentration ranges of heavy metals of $\mathrm{Cr}, \mathrm{Ni}$, $\mathrm{Cu}, \mathrm{Zn}, \mathrm{Cd}$, and $\mathrm{Pb}$ in Bohai Bay sediments were 51.32 
TABLE 1: Heavy metal concentrations in surface sediments of Bohai Bay and other Bays in China (mg/kg).

\begin{tabular}{|c|c|c|c|c|c|c|c|}
\hline Station & $\mathrm{Cr}$ & $\mathrm{Ni}$ & $\mathrm{Cu}$ & $\mathrm{Zn}$ & $\mathrm{Cd}$ & $\mathrm{Pb}$ & References \\
\hline Minimum & 51.32 & 21.88 & 16.84 & 45.31 & 0.11 & 20.69 & \multirow{4}{*}{ This study } \\
\hline Maximum & 94.33 & 47.04 & 34.99 & 84.19 & 0.18 & 28.33 & \\
\hline Mean & 79.73 & 36.56 & 28.70 & 72.83 & 0.15 & 25.63 & \\
\hline Variable coefficient (\%) & 11.39 & 13.84 & 12.71 & 12.04 & 10.29 & 7.25 & \\
\hline Intertidal Bohai Bay, China & 68.6 & 28.0 & 24.0 & 73.0 & 0.12 & 25.6 & {$[5]$} \\
\hline Southern Bohai Bay, China & 33.5 & 30.5 & 22.7 & 71.7 & 0.14 & 21.7 & [9] \\
\hline Western Bohai Bay, China & 53.1 & 31.4 & 27.9 & 83.6 & 0.13 & 20.5 & {$[8]$} \\
\hline Upper continental crust & 35 & 20 & 25 & 71 & 0.098 & 16.6 & {$[12]$} \\
\hline Yangtze Estuary, China & 78.9 & 31.8 & 30.7 & 94.3 & 0.26 & 27.3 & {$[18]$} \\
\hline Pearl River Estuary, China & 89.0 & 41.7 & 46.2 & 150 & n.d. & 59.3 & {$[19]$} \\
\hline Marine sediment quality I & 80 & n.d. & 35 & 150 & 0.5 & 60 & [20] \\
\hline Marine sediment quality II & 150 & n.d. & 100 & 350 & 1.5 & 130 & {$[20]$} \\
\hline Target* & 25 & 20 & 20 & 75 & 0.4 & 35 & {$[13]$} \\
\hline Trigger* & 50 & 35 & 55 & 150 & 1.0 & 65 & [13] \\
\hline Action ${ }^{*}$ & 80 & 40 & 65 & 200 & 1.5 & 75 & {$[13]$} \\
\hline
\end{tabular}

* Target indicates the desired quality for fairly clean sediment that is close to background levels. Trigger indicates that the sediment is moderately contaminated.

Action indicates heavily polluted sediments.

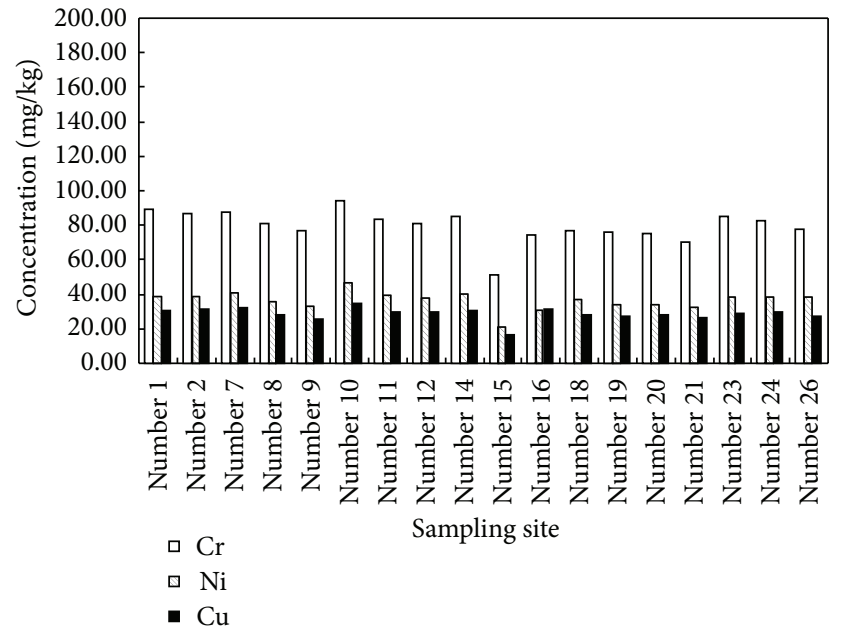

(a)

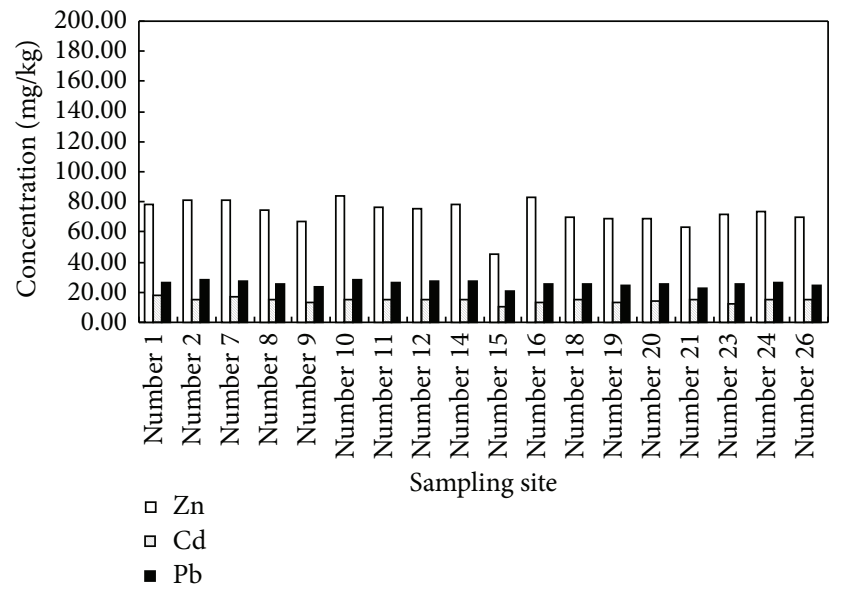

(b)

Figure 2: Spatial distribution of heavy metals in surface sediments of Bohai Bay.

94.33, 21.88 47.04, 16.86 34.99, 45.31 84.19, 0.11 0.18, and $20.69 \sim 28.33 \mathrm{mg} / \mathrm{kg}$, respectively; and the mean concentrations of these metals were $79.73,36.56,28.70,72.83,0.15$, and $25.63 \mathrm{mg} / \mathrm{kg}$, respectively. The order of mean concentrations in surface sediments was $\mathrm{Cr}>\mathrm{Zn}>\mathrm{Ni}>\mathrm{Cu}>\mathrm{Pb}>\mathrm{Cd}$. In the sediments from the Bohai Bay, the mean concentrations of the studied metals were slightly higher than the background values [12]. In addition, low variable coefficient $(<15 \%)$ of these metals showed that the heavy metals were evenly distributed in the Bohai Bay. In fact, the heavy metals concentrations in surface sediments of Bohai Bay were above those in the intertidal Bohai Bay, Southern Bohai Bay, and Western Bohai Bay, indicating that possible anthropogenic input was in the central part of Bohai Bay. However, heavy metals concentrations in surface sediments in Bohai Bay were below those in the other estuaries in China, such as Yangtze Estuary and Pearl River Estuary. In addition, the spatial distribution of heavy metals in sediments collected from Bohai Bay is shown in Figure 2 (Cd concentration is 100 times more than the actual concentration). From Figure 2, it can be seen that heavy metal concentrations in sediments close to center of Bay (number 10) were the highest among all sediments in the whole Bay (Figure 1).

Marine sediment quality (GB 18668-2002), established by China State Bureau of Quality and Technical Supervision (CSBTS, 2002), contains three standard criteria for marine sediments. The marine sediment quality I is applied to protect the habitats for marine life including natural, rare, and endangered species as well as the areas for human recreation and sports, while the marine sediment quality II is applied to 
TABLE 2: $I_{\text {geo }}$ values of heavy metals in surface sediments of Bohai Bay.

\begin{tabular}{|c|c|c|c|c|c|c|}
\hline Sampling sites & $\mathrm{Cr}$ & $\mathrm{Ni}$ & $\mathrm{Cu}$ & $\mathrm{Zn}$ & $\mathrm{Cd}$ & $\mathrm{Pb}$ \\
\hline $1 \#$ & $-0.01 / 0$ & $0.36 / 1$ & $0.23 / 1$ & $-0.08 / 0$ & $-0.24 / 0$ & $0.66 / 1$ \\
\hline $2 \#$ & $-0.05 / 0$ & $0.39 / 1$ & $0.24 / 1$ & $-0.03 / 0$ & $-0.47 / 0$ & $0.73 / 1$ \\
\hline $7 \#$ & $-0.03 / 0$ & $0.46 / 1$ & $0.31 / 1$ & $-0.04 / 0$ & $-0.34 / 0$ & $0.70 / 1$ \\
\hline $8 \#$ & $-0.15 / 0$ & $0.27 / 1$ & $0.11 / 1$ & $-0.16 / 0$ & $-0.49 / 0$ & $0.57 / 1$ \\
\hline 9\# & $-0.23 / 0$ & $0.13 / 1$ & $-0.03 / 0$ & $-0.30 / 0$ & $-0.62 / 0$ & $0.50 / 1$ \\
\hline $10 \#$ & $0.07 / 1$ & $0.65 / 1$ & $0.41 / 1$ & $0.02 / 1$ & $-0.50 / 0$ & $0.74 / 1$ \\
\hline $11 \#$ & $-0.11 / 0$ & $0.39 / 1$ & $0.17 / 1$ & $-0.12 / 0$ & $-0.44 / 0$ & $0.62 / 1$ \\
\hline $12 \#$ & $-0.15 / 0$ & $0.35 / 1$ & $0.16 / 1$ & $-0.14 / 0$ & $-0.44 / 0$ & $0.67 / 1$ \\
\hline $14 \#$ & $-0.09 / 0$ & $0.42 / 1$ & $0.20 / 1$ & $-0.08 / 0$ & $-0.46 / 0$ & $0.68 / 1$ \\
\hline $15 \#$ & $-0.81 / 0$ & $-0.46 / 0$ & $-0.64 / 0$ & $-0.87 / 0$ & $-0.98 / 0$ & $0.29 / 1$ \\
\hline $16 \#$ & $-0.28 / 0$ & $0.04 / 1$ & $0.27 / 1$ & $0.00 / 0$ & $-0.64 / 0$ & $0.61 / 1$ \\
\hline $18 \#$ & $-0.22 / 0$ & $0.26 / 1$ & $0.09 / 1$ & $-0.25 / 0$ & $-0.46 / 0$ & $0.58 / 1$ \\
\hline $19 \#$ & $-0.25 / 0$ & $0.22 / 1$ & $0.04 / 1$ & $-0.27 / 0$ & $-0.67 / 0$ & $0.54 / 1$ \\
\hline $20 \#$ & $-0.25 / 0$ & $0.21 / 1$ & $0.08 / 1$ & $-0.27 / 0$ & $-0.54 / 0$ & $0.60 / 1$ \\
\hline $21 \#$ & $-0.35 / 0$ & $0.11 / 1$ & $-0.01 / 0$ & $-0.39 / 0$ & $-0.49 / 0$ & $0.41 / 1$ \\
\hline 23\# & $-0.08 / 0$ & $0.37 / 1$ & $0.15 / 1$ & $-0.20 / 0$ & $-0.72 / 0$ & $0.61 / 1$ \\
\hline $24 \#$ & $-0.12 / 0$ & $0.35 / 1$ & $0.16 / 1$ & $-0.17 / 0$ & $-0.49 / 0$ & $0.62 / 1$ \\
\hline $26 \#$ & $-0.22 / 0$ & $0.31 / 1$ & $0.07 / 1$ & $-0.25 / 0$ & $-0.46 / 0$ & $0.55 / 1$ \\
\hline Average & $-0.19 / 0$ & $0.27 / 1$ & $0.11 / 1$ & $-0.20 / 0$ & $-0.53 / 0$ & $0.59 / 1$ \\
\hline
\end{tabular}

regulating general industrial use and coastal tourism. Based on marine sediment quality (GB 18668-2002), the overall mean concentrations of all selected heavy metals in Bohai Bay are below those value of the marine sediment quality I, indicating that the overall sediments quality in the Bohai Bay has not been obviously impacted by these six heavy metals. However, the mean concentration of $\mathrm{Cr}$ was close to the marine sediment quality I and $\mathrm{Cr}$ concentrations in some sampling sites have higher values than the value of marine sediment quality I, especially for the number 10 (Figure 2).

Sediment quality guidelines (SQGs) have been developed to deal with environmental concerns, and a stricter criterion in Hong Kong was also chosen to assess the contamination level of individual metals in sediments of the Bohai Bay (Table 1) [13]. The concentrations of $\mathrm{Cu}, \mathrm{Pb} \mathrm{Zn}$, and $\mathrm{Cd}$ in sediments from $94.4 \%, 100 \%, 44.4 \%$, and $100 \%$ of stations, respectively, were lower than "target" values and showed no signs of contamination. The contents of $\mathrm{Cr}$ at $100 \%$ of stations and $\mathrm{Ni}$ at $66.7 \%$ of stations were higher than the "trigger" values which are regarded as the upper limit of the desired quality for fairly clean sediments, indicating Bohai Bay sediments were moderately contaminated for $\mathrm{Cr}$ and Ni. In fact, there were $55.6 \%$ and $16.7 \%$ sediments heavily polluted by $\mathrm{Cr}$ and $\mathrm{Ni}$ (Figure 2 and Table 1).

3.2. Pollution Assessment. The Geoaccumulation Index $\left(I_{\text {geo }}\right)$ introduced by Müller (1979) was used to assess metal pollution in sediments of Bohai Bay [14]. Geoaccumulation Index is expressed as follows:

$$
I_{\text {geo }}=\log _{2}\left(\frac{C_{n}}{1.5 B_{n}}\right) \text {, }
$$

where $C_{n}$ is the measured concentration of heavy metal $(n)$ in the sediment, $B_{n}$ is the geochemical background value of heavy metal $(n)$, and 1.5 is the background matrix correction factor due to lithogenic effects. In the present study, $B_{n}$ was selected from the literature [15]. Geoaccumulation Index includes seven grades from Class $0\left(I_{\text {geo }} \leq 0\right)$ to Class 6 $\left(I_{\text {geo }} \geq 5\right)$. The $I_{\text {geo }}$ is associated with a qualitative scale of pollution intensity; samples may be classified as unpolluted $\left(I_{\text {geo }} \leq 0\right)$, unpolluted to moderately polluted $\left(0 \leq I_{\text {geo }} \leq 1\right)$, moderately polluted ( $1 \leq I_{\text {geo }} \leq 2$ ), moderate to strongly polluted $\left(2 \leq I_{\text {geo }} \leq 3\right)$, strongly polluted $\left(3 \leq I_{\text {geo }} \leq 4\right)$, strongly to extremely polluted $\left(4 \leq I_{\text {geo }} \leq 5\right)$, and extremely polluted $\left(I_{\text {geo }} \geq 5\right)$.

Based on the $I_{\text {geo }}$ data and the Geoaccumulation Index, the results of the $I_{\text {geo }}$ values and pollution level of heavy metals of surface sediment in Bohai Bay are shown in Table 2. In general, the average $I_{\text {geo }}$ values are -0.91 for $\mathrm{Cr}, 0.27$ for $\mathrm{Ni}$, 0.11 for $\mathrm{Cu},-0.20$ for $\mathrm{Zn},-0.53$ for $\mathrm{Cd}$, and 0.59 for $\mathrm{Pb}$. The order of average $I_{\text {geo }}$ values was $\mathrm{Pb}>\mathrm{Ni}>\mathrm{Cu}>\mathrm{Cr}>\mathrm{Zn}>$ $\mathrm{Cd}$. Among the average $I_{\text {geo }}$ of $\mathrm{Cr}, \mathrm{Zn}$ and $\mathrm{Cd}$ were less than zero $\left(I_{\text {geo }} \leq 0\right)$, which were classified as "unpolluted" level. However, the $I_{\text {geo }}$ value of $\mathrm{Cr}$ and $\mathrm{Zn}$ in sampling site number 10 was more than zero, which were ranked as "unpolluted to moderately polluted" level. In addition, the average $I_{\text {geo }}$ values of $\mathrm{Ni}, \mathrm{Cu}$, and $\mathrm{Pb}$ were ranked as "unpolluted to moderately polluted" level $\left(0 \leq I_{\text {geo }} \leq 1\right)$. However, the $I_{\text {geo }}$ value of $\mathrm{Ni}$ and $\mathrm{Cu}$ in sampling site number 15 was less than zero. In general, the worst pollution of heavy metals occurred in sampling site number 10 and the lightest pollution of heavy metals was in sampling site number 15 .

3.3. $\mathrm{Pb}$ Isotopic Compositions in Surface Sediments. The results of $\mathrm{Pb}$ isotope ratios of sediment samples in Bohai Bay and other environmental samples (natural sources, ores in 
TABLE 3: Comparison of $\mathrm{Pb}$ isotope ratios of surface sediments in Bohai and other sources in environment.

\begin{tabular}{lccr}
\hline Sample & ${ }^{206} \mathrm{~Pb} /{ }^{207} \mathrm{~Pb}$ & ${ }^{208} \mathrm{~Pb} /{ }^{207} \mathrm{~Pb}$ & $\mathrm{Reference}$ \\
\hline Sediments in Bohai Bay & $1.159-1.185($ average 1.176$)$ & $2.456-2.482$ (average 2.473) & In this study \\
Natural sources & $1.178-1.202$ & $2.462-2.526$ & In this study \\
Ores in this region & $1.143-1.205$ & $2.446-2.494$ & {$[21]$} \\
Vehicle exhaust (leaded) & 1.099 & 2.4349 & {$[22]$} \\
Vehicle exhaust (unleaded) & 1.1468 & 2.4358 & {$[22]$} \\
Unburned coal & 1.1628 & 2.4548 & {$[22]$} \\
Air deposition & $1.150-1.194$ & $2.428-2.485$ & {$[16]$} \\
\hline
\end{tabular}

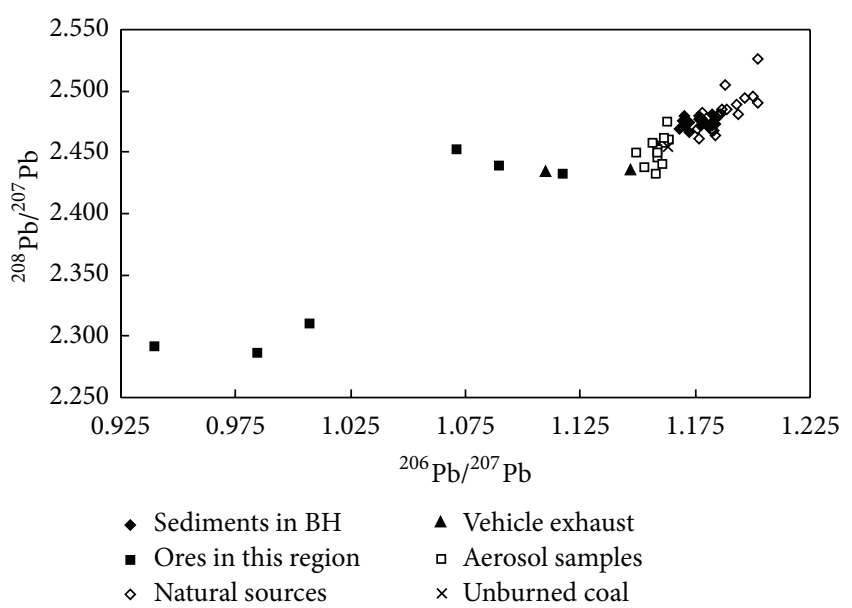

FIGURE 3: Comparison of the $\mathrm{Pb}$ isotopic ratios in sediments of Bohai Bay and other sources.

this region, vehicle exhaust, aerosol samples, and unburned coal) are shown in Table 3. Lead isotopic ratios ranged from 1.159 to 1.185 for ${ }^{206} \mathrm{~Pb} /{ }^{207} \mathrm{~Pb}$ and 2.456 to 2.482 for ${ }^{208} \mathrm{~Pb} /{ }^{207} \mathrm{~Pb}$. From Table 3, it can be seen that sediments from all sampling sites have relative lower values of ${ }^{206} \mathrm{~Pb} /{ }^{207} \mathrm{~Pb}$ ratios close to those values in pollution sources, suggesting the influence of anthropogenic inputs in Bohai Bay. In order to assess $\mathrm{Pb}$ contamination and identify potential $\mathrm{Pb}$ sources of sediments, the correlation between $1 / \mathrm{Pb}$ concentrations and ${ }^{206} \mathrm{~Pb} /{ }^{207} \mathrm{~Pb}$ ratios were analyzed. The analytic results showed that the relationship was not obviously correlated $\left(R^{2}=0.2772\right)$, indicating that $\mathrm{Pb}$ sources of sediments were relatively complicated and cannot be simply attributed to binary mixing process of two sources [6].

Source apportionment can also be accomplished by analyzing the $\mathrm{Pb}$ isotopic radios $\left({ }^{206} \mathrm{~Pb} /{ }^{207} \mathrm{~Pb}\right.$ and $\left.{ }^{208} \mathrm{~Pb} /{ }^{207} \mathrm{~Pb}\right)$ in the environmental samples and major pollution sources with a lines mixing model [6]. The comparison between ${ }^{206} \mathrm{~Pb} /{ }^{207} \mathrm{~Pb}$ and ${ }^{208} \mathrm{~Pb} /{ }^{207} \mathrm{~Pb}$ ratios in sediments and other environmental samples showed that the ${ }^{206} \mathrm{~Pb} /{ }^{207} \mathrm{~Pb}$ ratios in surface sediments collected from Bohai Bay were obviously higher than those from the emission of vehicle exhaust and $\mathrm{Pb}$ ores mining, indicating that these two anthropogenic inputs were not important factors for $\mathrm{Pb}$ pollution in sediments (Figure 3). Wang et al. also have confirmed that lead concentrations of atmospheric aerosols in Tianjin were decreased significantly after the leaded gasoline ban [16]. In fact, the
${ }^{206} \mathrm{~Pb} /{ }^{207} \mathrm{~Pb}$ and ${ }^{208} \mathrm{~Pb} /{ }^{207} \mathrm{~Pb}$ ratios in sediments were significantly similar to those in natural sources, unburned coal, and aerosol samples in the city of Tianjin. In the northern part of China, coal became one of most important energy resources in urban economical and industrial development. The leaded particular matter from coal combustion and coupled with the urban dusts (contain a mass of cement material) can be transported to the Bohai Bay by atmospheric deposition and surface river runoff. Previous study has shown that a large amount of $\mathrm{Pb}$ was supplied by the precipitation of aerosols in coastal environments and coal burning from power generation plants and other industrial activities may be the major source of $\mathrm{Pb}$ in its sediments [17]. Therefore, $\mathrm{Pb}$ contamination in the sediments of Bohai Bay may be controlled by the mix process of coal combustion, aerosol particles deposition, and natural sources.

\section{Conclusion}

Our investigation of heavy metals $(\mathrm{Cr}, \mathrm{Ni}, \mathrm{Cu}, \mathrm{Zn}, \mathrm{Cd}$, and $\mathrm{Pb}$ ) in surface sediments collected from Bohai Bay showed that the mean concentrations of the studied metals were slightly higher than the background values. However, the heavy metals concentrations in surface sediments in Bohai Bay were below the other important bays or estuaries in China. The assessment by Geoaccumulation Index indicated that $\mathrm{Cr}, \mathrm{Zn}$, and $\mathrm{Cd}$ were at the "unpolluted" level, while $\mathrm{Ni}, \mathrm{Cu}$, and $\mathrm{Pb}$ were ranked as "unpolluted to moderately polluted" level. The pollution level of the heavy mental was $\mathrm{Pb}$ $>\mathrm{Ni}>\mathrm{Cu}>\mathrm{Cr}>\mathrm{Zn}>\mathrm{Cd}$. The $\mathrm{Pb}$ isotopic ratios in surface sediments varied from 1.159 to 1.185 for ${ }^{206} \mathrm{~Pb} /{ }^{207} \mathrm{~Pb}$ and from 2.456 to 2.482 for ${ }^{208} \mathrm{~Pb} /{ }^{207} \mathrm{~Pb}$. $\mathrm{Pb}$ sources in sediments from Bohai Bay were more complicated (more than two sources), and there may exist various pollution sources. Compared with the $\mathrm{Pb}$ isotopic radios in other sources, coal combustion, aerosol particles deposition, and natural sources may be the major sources for $\mathrm{Pb}$ pollution in surface sediments of Bohai Bay.

\section{Conflict of Interests}

The authors declare that there is no conflict of interests regarding the publication of this paper.

\section{Acknowledgment}

This work was supported by the National Instrumentation Program (Grant no. 2011YQ14015009). 


\section{References}

[1] J. H. Tao, "Numerical simulation of aquatic eco-environment of Bohai Bay," in Proceedings of the Conference of Global Chinese Scholars on Hydrodynamics, Shanghai, China, 2006.

[2] L. G. Zheng, G. Wang, and G. Yao, "The study of heavy metal in offshore and environmental significance," Marine Geology Letters, vol. 18, no. 12, pp. 1-5, 2003 (Chinese).

[3] A. Tessier, P. G. C. Campbell, and M. Bisson, "Sequential extraction procedure for the speciation of particulate trace metals," Analytical Chemistry, vol. 51, no. 7, pp. 844-851, 1979.

[4] S. C. Wong, X. D. Li, G. Zhang, S. H. Qi, and Y. S. Min, "Heavy metals in agricultural soils of the Pearl River Delta, South China," Environmental Pollution, vol. 119, no. 1, pp. 33-44, 2002.

[5] B. Gao, X. R. Liang, H. D. Zhou, and X. L. Tu, "Lead isotopes as a tracer of $\mathrm{Pb}$ origin in the sediments from Beijiang River, South China," Water Science and Technology, vol. 66, no. 12, pp. 2613-2619, 2012.

[6] H. Cheng and Y. Hu, "Lead (Pb) isotopic fingerprinting and its applications in lead pollution studies in China: a review," Environmental Pollution, vol. 158, no. 5, pp. 1134-1146, 2010.

[7] Y. W. Qin, W. Meng, B. H. Zheng, L. Zhang, and Y. B. Su, "Contaminative features of heavy metals for tidal sediment cores in Tianjin Bohai Bay," Environmental Science, vol. 27, no. 2, pp. 268-273, 2006 (Chinese).

[8] H. Feng, H. Jiang, W. Gao et al., "Metal contamination in sediments of the western Bohai Bay and adjacent estuaries, China," Journal of Environmental Management, vol. 92, no. 4, pp. 1185-1197, 2011.

[9] B. Q. Hu, G. G. Li, J. Q. Bi, J. T. Zhao, and R. Y. Bu, "Spatial distribution and ecotoxicological risk assessment of heavy metals in surface sediments of the Southern Bohai Bay, China," Environmental Science and Pollution Research, vol. 20, pp. 40994110, 2013.

[10] Y. Liu, H. C. Liu, and X. H. Li, "Simultaneous and precise determination of 40 trace elements in rock samples using ICPMS," Geochimica, vol. 25, no. 6, pp. 552-226, 1966 (Chinese).

[11] B.-Q. Zhu, Y.-W. Chen, and J.-H. Peng, "Lead isotope geochemistry of the urban environment in the pearl river delta," Applied Geochemistry, vol. 16, no. 4, pp. 409-417, 2001.

[12] S. R. Taylor and S. M. Mclenman, "The chemical composition evolution of the continental crust," Reviews of Geophysics, vol. 33, pp. 241-265, 1995.

[13] M. M. Lau, R. C. Rootham, and G. C. Bradley, "A strategy for the management of contaminated dredged sediment in Hong Kong," Journal of Environmental Management, vol. 38, no. 2, pp. 99-114, 1993.

[14] G. Müller, "Schwermetalle in den sedimenten des Rheinsveränderungen seitt 1971," Umschan, vol. 79, pp. 778-783, 1979.

[15] S. Y. Li, F. M. Miao, and G. X. Liu, “The distribution and environment background values of the heavy metals in sediment of Bohai Sea," Chinese Environment Science, vol. 14, no. 5, pp. 370376, 1994 (Chinese).

[16] W. Wang, X. Liu, L. Zhao, D. Guo, X. Tian, and F. Adams, "Effectiveness of leaded petrol phase-out in Tianjin, China based on the aerosol lead concentration and isotope abundance ratio," Science of the Total Environment, vol. 364, no. 1-3, pp. 175$187,2006$.

[17] X. Li, O. W. H. Wai, Y. S. Li, B. J. Coles, M. H. Ramsey, and I. Thornton, "Heavy metal distribution in sediment profiles of the
Pearl River estuary, South China," Applied Geochemistry, vol. 15, no. 5, pp. 567-581, 2000.

[18] W. Zhang, H. Feng, J. Chang, J. Qu, H. Xie, and L. Yu, "Heavy metal contamination in surface sediments of Yangtze River intertidal zone: an assessment from different indexes," Environmental Pollution, vol. 157, no. 5, pp. 1533-1543, 2009.

[19] H.-Y. Zhou, X.-T. Peng, and J.-M. Pan, "Distribution, source and enrichment of some chemical elements in sediments of the Pearl River Estuary, China," Continental Shelf Research, vol. 24, no. 16, pp. 1857-1875, 2004.

[20] CSBTS, Marine Sediment Quality, Standards Press of China, Beijing, China, 2002.

[21] B. Zhu, "The mapping of geochemical provinces in China based on $\mathrm{Pb}$ isotopes," Journal of Geochemical Exploration, vol. 55, no. 1-3, pp. 171-181, 1995.

[22] J. Chen, M. Tan, Y. Li et al., "A lead isotope record of shanghai atmospheric lead emissions in total suspended particles during the period of phasing out of leaded gasoline," Atmospheric Environment, vol. 39, no. 7, pp. 1245-1253, 2005. 

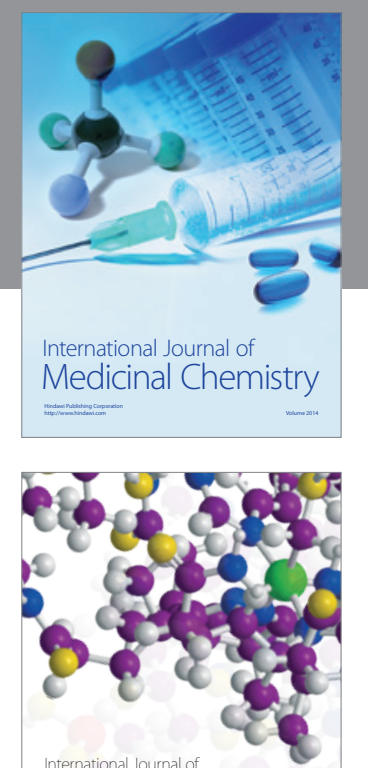

\section{Carbohydrate} Chemistry

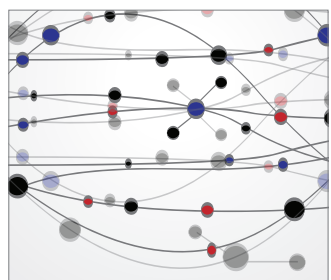

The Scientific World Journal
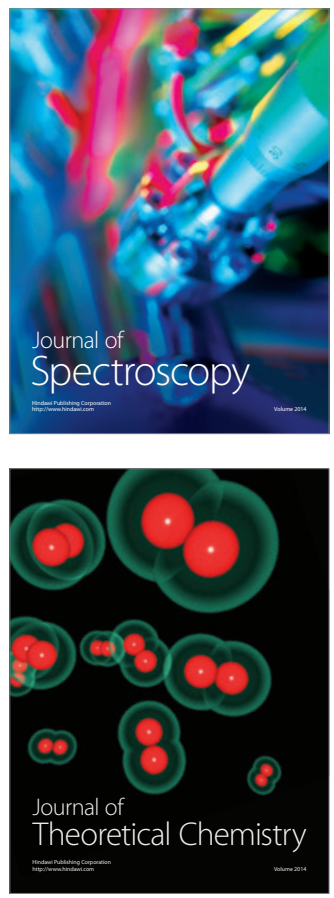
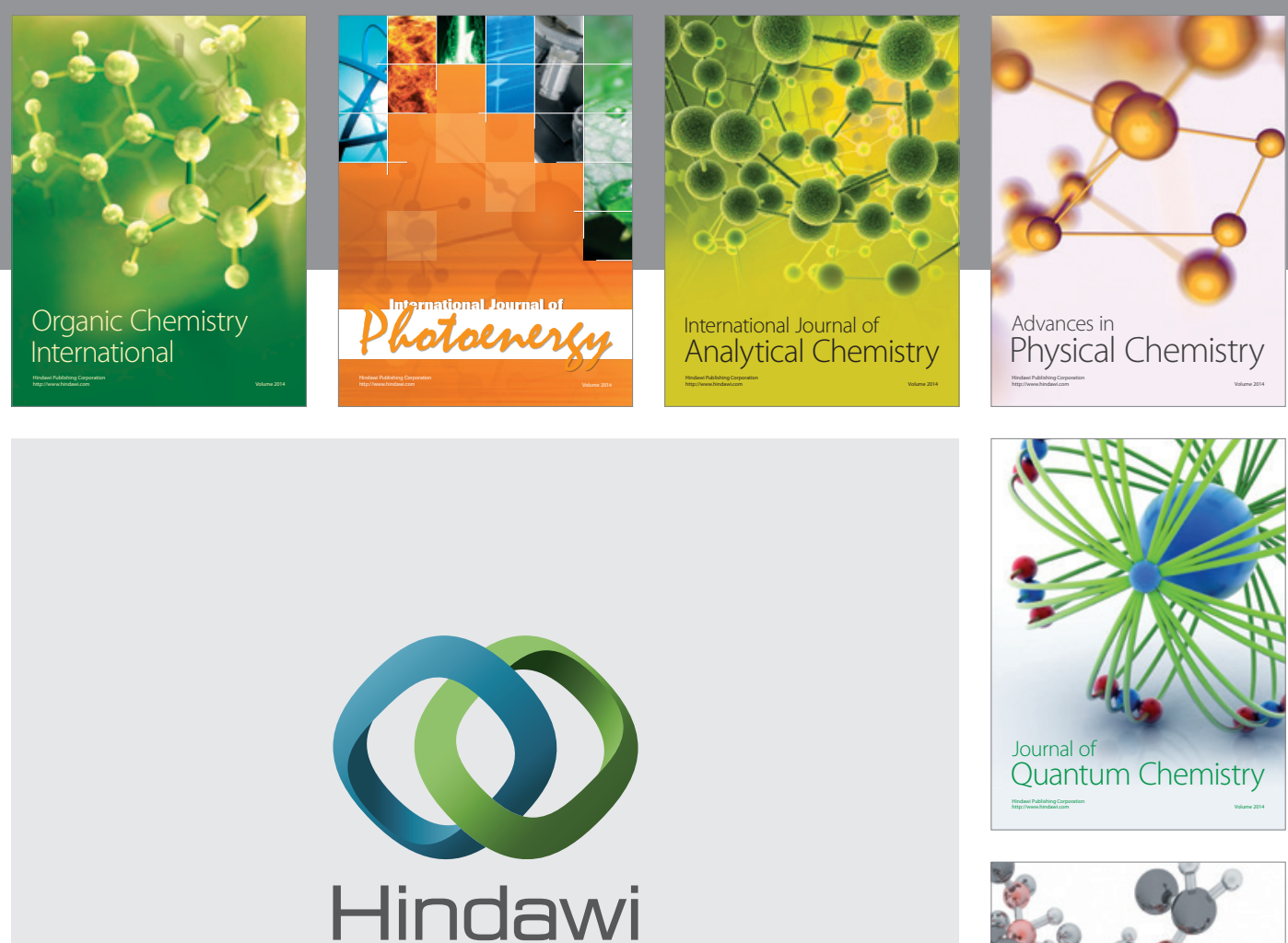

Submit your manuscripts at

http://www.hindawi.com

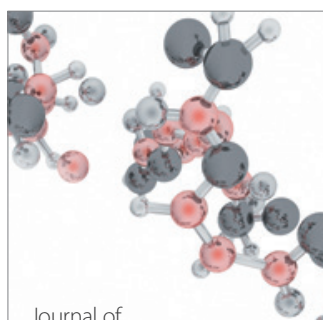

Analytical Methods

in Chemistry

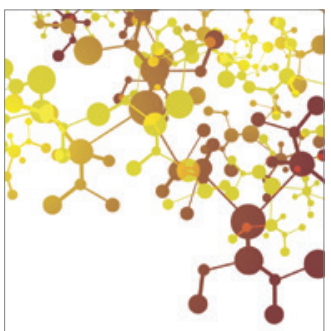

Journal of

Applied Chemistry

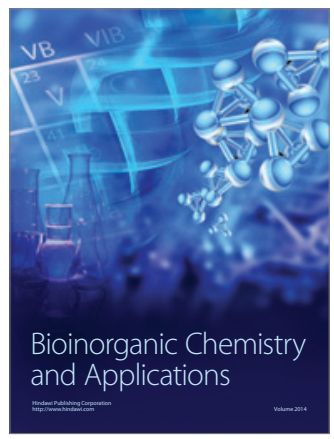

Inorganic Chemistry
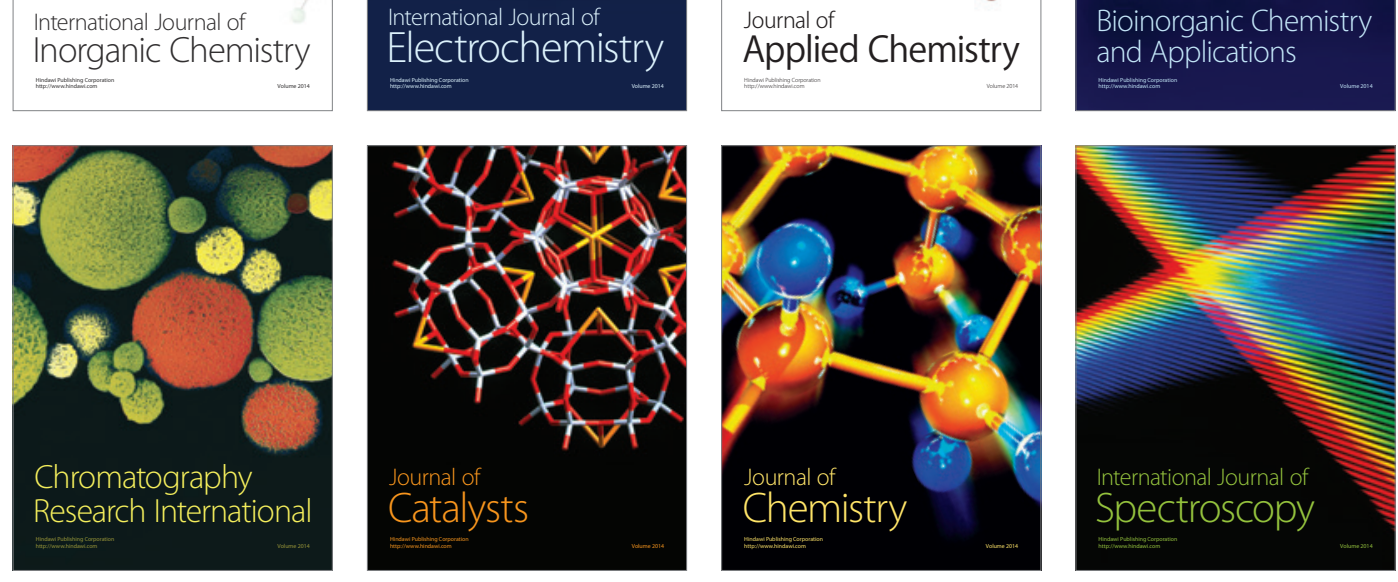